\title{
Two new species of Afroarabiella Yakovlev, 2008 (Lepidoptera, Cossidae) from Sudan and Ethiopia
}

\author{
Roman V. YAKOVLEV ${ }^{1, *} \&$ Thomas J. WITT ${ }^{2}$ \\ ${ }^{1}$ Altai State University, South Siberian Botanical Garden, Lenina pr. 61, RF-656049, Barnaul, Russia. \\ ${ }^{1}$ Tomsk State University, Laboratory of Biodiversity and Ecology, \\ Lenina pr. 36, 634050 Tomsk, Russia. \\ ${ }^{2}$ Museum Witt, Tengstrasse 33, D-80796, Munich, Germany. \\ ${ }^{*}$ Corresponding author: yakovlev_asu@mail.ru \\ ${ }^{2}$ Email: thomas@witt-thomas.com \\ ${ }^{1}$ urn:lsid:zoobank.org:author:18B1DBFC-045D-4FDB-A872-F32854180441 \\ ${ }^{2}$ urn:lsid:zoobank.org:author:C13CF2AA-AA3B-4B13-B1DF-DE8DCCD54C57
}

\begin{abstract}
The paper describes two new species of Afroarabiella (Cossidae): A. sulaki sp. nov. from Sudan and A. strohlei sp. nov. from Ethiopia. For all the species of the genus Afroarabiella images and distribution maps are given.
\end{abstract}

Keywords. Cossidae, Carpenter moths, Afroarabiella, new species, Lepidoptera.

Yakovlev R.V. \& Witt T.J. 2016. Two new species of Afroarabiella Yakovlev, 2008 (Lepidoptera, Cossidae) from Sudan and Ethiopia. European Journal of Taxonomy 240: 1-8. http://dx.doi.org/10.5852/ejt.2016.240

\section{Introduction}

The genus Afroarabiella Yakovlev, 2008 (Lepidoptera: Cossidae) was established for Cossus tahamae Wiltshire, 1949 (Yakovlev 2008). A supplement to the description of this genus was given by Mey (2015). In addition, the subgenus Meyoarabiella Yakovlev, 2008 (type species - M. meyi Yakovlev, 2008, widespread in the Republic of South Africa, Northern Cape has received the status of genus. Mey (2015) also presented all the known discoveries of the genus Afroarabiella from South Africa and Namibia. Currently, the genus includes nine species: A. buchanani (Rothschild, 1921) (Figs 1, 16) (Niger), A. fanti (Hampson, 1910) (Figs 2, 16) (Ghana), A. namaquensis Yakovlev, 2014 (Figs 3, 16) (South Africa), A. ochracea (Gaede, 1930) (Figs 4, 16) (Congo, Tanzania), A. polioptera (Clench, 1959) (Figs 5, 16) (Namibia, South Africa), A. politzari Yakovlev, 2008 (Figs 6, 16) (Kenya), A. tahamae (Wiltshire, 1949) (Figs 7, 16) (Saudi Arabia, Yemen), A. tanzaniae Yakovlev, 2011 (Figs 8, 16) (Tanzania), A. ukambani Yakovlev, 2008 (Figs 9, 16) (Kenya, Southern Somalia). Thus, the genus is widespread from Saudi Arabia across Africa to South Africa (Yakovlev \& Dubatolov 2013; Yakovlev 2014, 2015; Mey 2015). Representatives of the genus are rare in collections, possibly due to their small size and also because they can easily be mixed up with specimens of Noctuoidea or "Microlepidoptera" and stored in museums as non-sorted materials. 


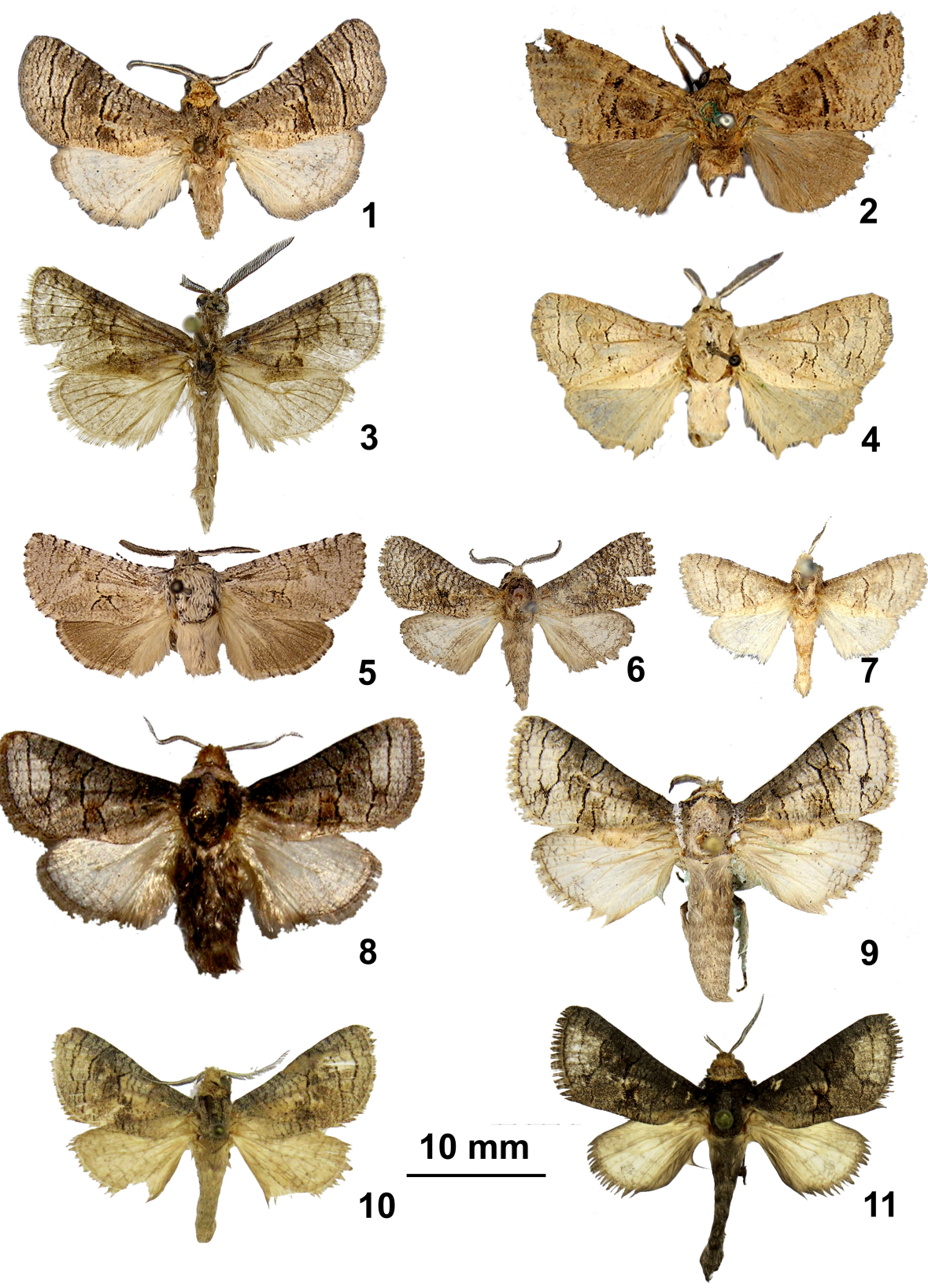

Figs 1-11. Afroarabiella species (adult, holotypes). 1. Afroarabiella buchanani (Rothschild, 1921), Mts. Baguezan, Asben [Niger Republic, Sahel, Air Mountains, Baguezan Mt.] (Natural History Museum, London). 2. A. fanti (Hampson, 1910), Gold Coast, Ashanti, Obuassi [Ghana, Ashanti Prov., Obuassi] (Natural History Museum, London). 3. A. namaquensis Yakovlev, 2014, Republic of South Africa, Northern Cape, $100 \mathrm{~km}$ W Upington, Augrabies N.[ational] P.[ark], Orange river, 28.34'60" S, 20.15'57" E (Zoological Institute, Saint-Petersburg). 4. A. ochracea (Gaede, 1930), Chaine Luitpold [Congo] (Natural History Museum, London). 5. A. polioptera (Clench, 1959), Brandberg [Namibia] (Zoological collection of the Bavarian State, Munich). 6. A. politzari Yakovlev, 2008, Kenya, Kaputir (Zoological collection of the Bavarian State, Munich). 7. A. tahamae (Wiltshire, 1949), Buraiman, coastal plain (Ar.: Tahama), near Jedda, Saudi Arabia (Natural History Museum, London). 8. A. tanzaniae Yakovlev, 2011, Tanzania, Lake Sereri (Museum of Natural History, Budapest). 9. A. ukambani Yakovlev, 2008, Kenya, Kibwezi (Zoological collection of the Bavarian State, Munich). 10. A. sulaki sp. nov. 11. A. strohlei sp. nov. 
During studies of Lepidoptera performed by our colleagues Harald Sulak (Munich) and Manfred Ströhle (Weiden) two new species of the genus Afroarabiella were found. Their descriptions are given below.

\title{
Material and methods
}

All specimens were collected using light traps. Preparation of genitalia is necessary for the identification of Cossidae. Dissections were performed with standard methods. Male genitalia were mounted in euparal on slides following Lafontaine (2004). Genitalia slides were examined with the use of a Zeiss Stemi 2000 C microscope, and images were taken with the Olympus XC 50 camera.

\section{Results}

\author{
Class Hexapoda Blainville, 1816 \\ Order Lepidoptera Linnaeus, 1758 \\ Superfamily Cossoidea Leach, [1815] \\ Family Cossidae Leach, [1815] \\ Subfamily Cossinae Leach, [1815] \\ Genus Afroarabiella Yakovlev, 2008 \\ Afroarabiella sulaki sp. nov. \\ urn:Isid:zoobank.org:act:B4ACF01C-2639-4A5E-A9B8-7B296CCFEBAB
}

Figs 10, 12, 14, 16.

\section{Diagnosis}

By external characters Afroarabiella sulaki sp. nov. can be confused with A. tahamae, but differs from it by the following features: the grey costal margin of the fore wing, the longer transtilla process, the long needle-like cornutus and the phallus smoothly curved in its basal third.

\section{Etymology}

The new species is named after the German lepidopterist Harald Sulak (Munich).

\section{Material examined}

\section{Holotype}

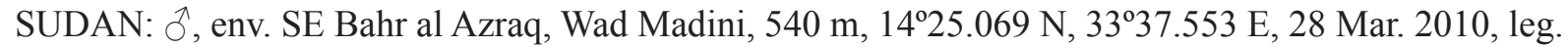
Harald Sulak (Museum Witt, Munich; GenPr Heterocera MWM 25.289).

\section{Paratype}

SUDAN: $1{ }^{\lambda}$, Province of Nahr on the Nile, 390 m, 16025.189 N, 33²14.575 E, 20 Mar. 2010, leg. Harald Sulak (Museum Witt, Munich).

\section{Description}

\section{Male}

EXTERNAL CHARACTERs. Length of fore wing $11 \mathrm{~mm}$, wingspan $22 \mathrm{~mm}$. Front and patagia ochre-brown. Antennae bipectinate. Thorax grey. Abdomen pale yellow. Fore wing wide with rounded apex; pattern of thin undulated transverse lines; costal margin of wing grey, pale yellow portion in discal area; dim pale brown fields with blurry outline in post-discal area; hind margin of wing, submarginal and marginal areas greyish-brown; marginal band thin $(0.5 \mathrm{~mm})$, pale yellow with even edges; fringe pale brown, unicolorous. Hind wing pale yellow with poorly expressed pattern of rare grey strokes; fringe pale yellow. 
MALE GenitALIA. Uncus long, edges almost parallel, apex rounded; gnathos arms rather thick, of middle length; gnathos poorly sclerotized, covered with small spines; valve with wide base, gradually tapering caudally, with wide rounded poorly sclerotized apex; area of expressed sclerotization on costal margin of valve from base to middle; transtilla process hook-likely bent, thin, with wide base and tapered apex; juxta large, saddle-lake, with two lateral processes; lateral process of juxta large, elongated, edges parallel, apex rounded; saccus of middle size, semicircular; phallus slightly shorter than valve, with thick base and strong caudal tapering (apex tapered), slightly curved in basal third; vesica aperture in dorsal-apical position, in length about $1 / 3$ of phallus; vesica with long needle-like cornutus, located along phallus axis.

\section{Female}

Unknown.

\section{Remarks}

The paratype is a little smaller. Length of fore wing $10 \mathrm{~mm}$.

\section{Distribution}

Sudan (Provinces Al Jazirah and Nahr an Nil).

\section{Flight period}

March.
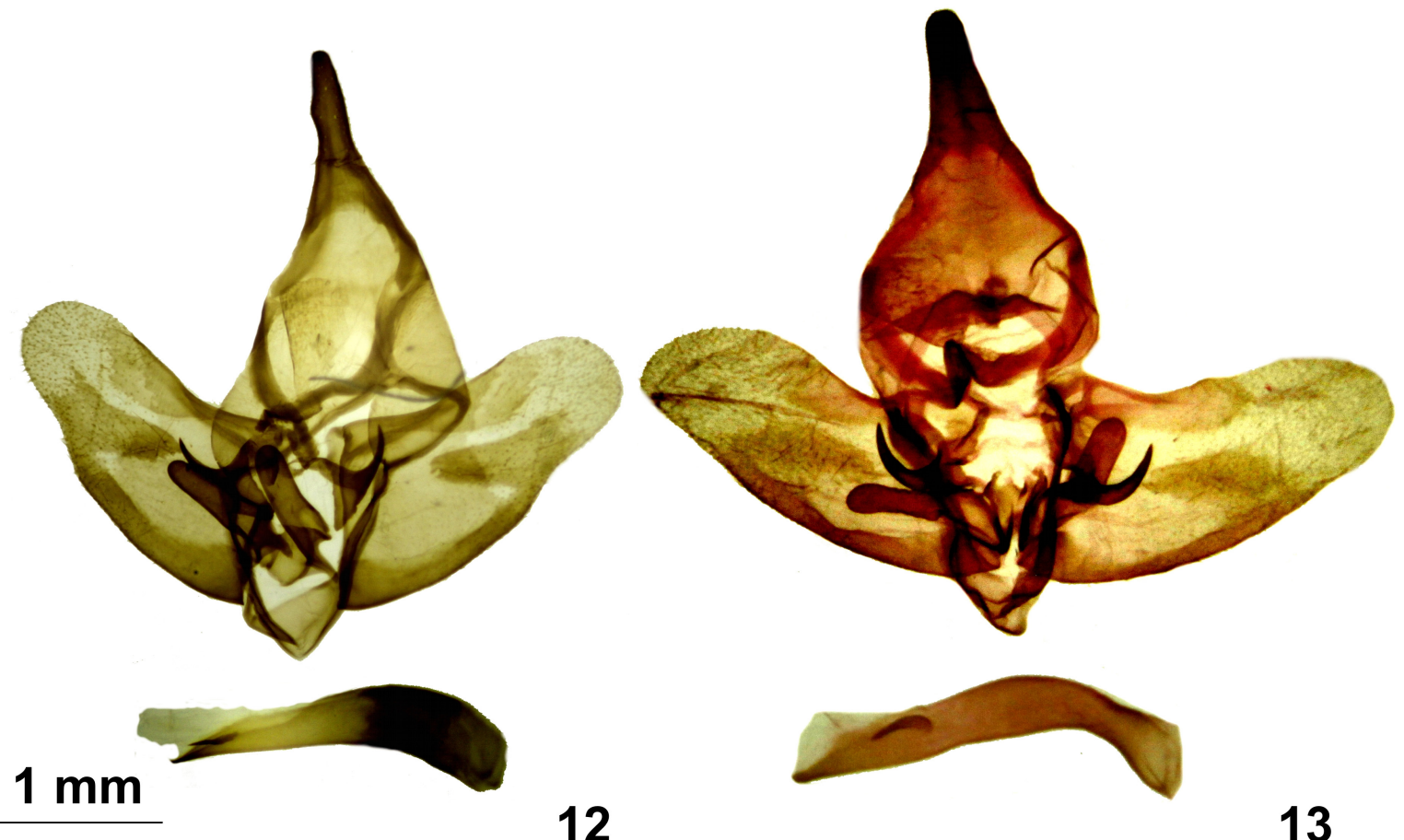

Figs 12-13. Afroarabiella species (male genitalia). 12. A. sulaki sp. nov., male genitalia. 13. A. strohlei sp. nov., male genitalia. 
Afroarabiella strohlei sp. nov.

urn:Isid:zoobank.org:act:55F15338-7A34-4FB8-9EB2-B67541E8D33C

Figs 11, 13, 15-16

\section{Diagnosis}

Afroarabiella strohlei sp. nov. is distinctive compared to other Afroarabiella species by virtue of its very dark wings and the male genitalia structure: the strongly tapered phallus in its basal third and the sickleshaped cornutus slightly tapered at apex.
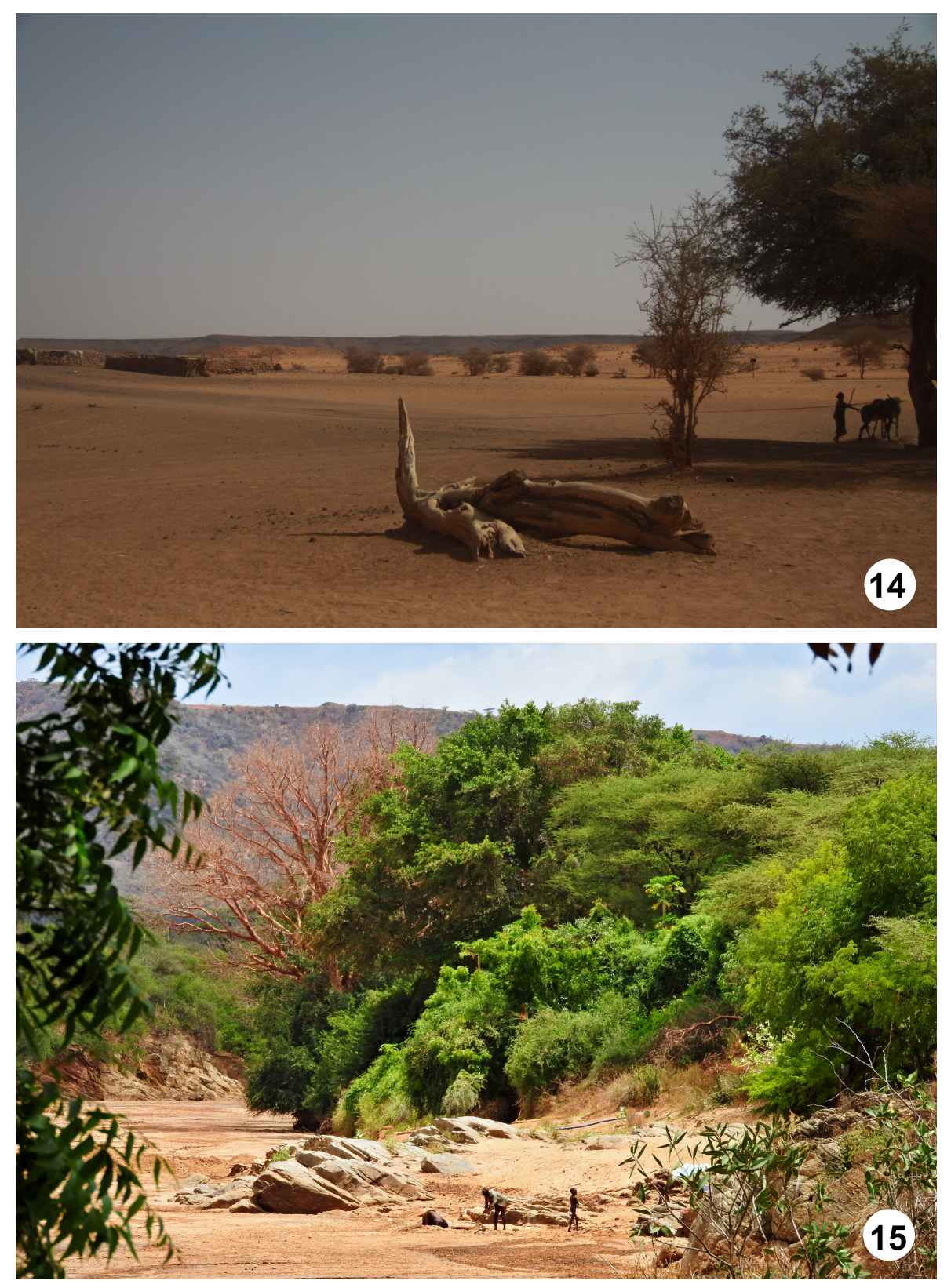

Figs 14-15. Afroarabiella species (type localities). 14. A. sulaki sp. nov., type locality (photo by H. Sulak). 15. A. strohlei sp. nov., type locality (photo by M. Ströhle). 


\section{Etymology}

The new species is named after the well-known German lepidopterist Manfred Ströhle (Weiden).

\section{Material examined}

\section{Holotype}

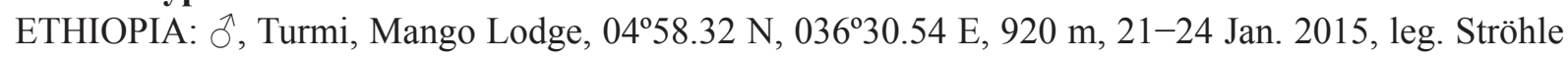
(collection of M. Ströhle, Weiden; Coss-MSW/2015/31).

\section{Paratype}

ETHIOPIA: 1 ô, same data as holotype (collection of M. Ströhle, Weiden).

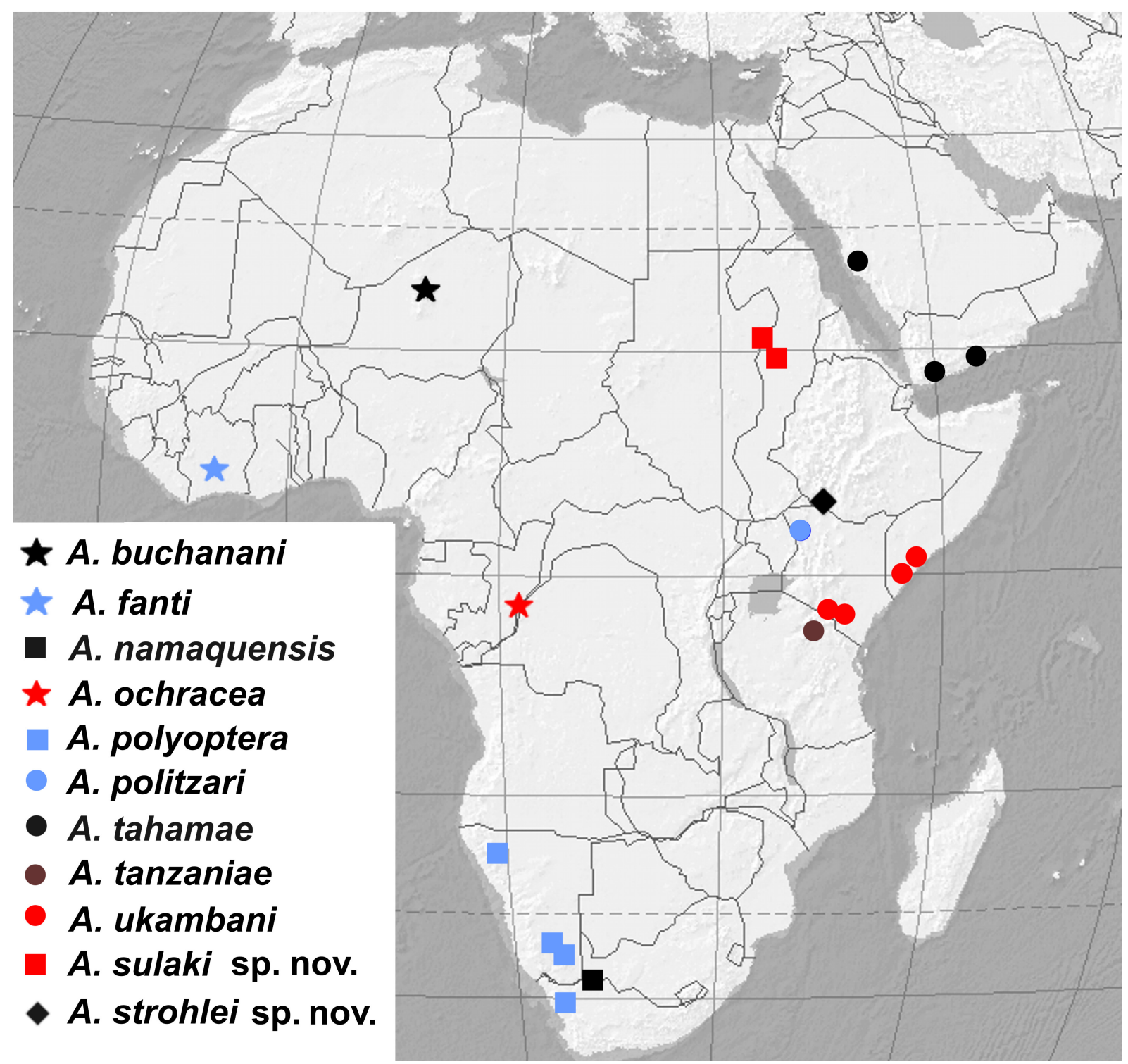

Fig. 16. Map of the distribution of Afroarabiella species. 


\section{Description}

\section{Male}

EXTERNAL CHARACTERs. Length of fore wing $12 \mathrm{~mm}$, wingspan $24 \mathrm{~mm}$. Front and patagia ginger brown. Antennae bipectinate. Thorax brown. Abdomen pale grey. Fore wing wide, apex rounded, color dark grey with pattern of poorly noticeable dark undulate lines and thin X-shaped band in post-discal area; pale grey portion in submarginal area; marginal band very thin (about $1 / 3 \mathrm{~mm}$ ), pale grey; fringe grey, unicolorous. Hind wing pale yellow with hardly expressed pattern of rare grey strokes; fringe grey.

MALE GENITALIA. Uncus long, gradually narrowing from base to apex, apex rounded; gnathos arms rather thick, of middle length; gnathos poorly sclerotized; valve slightly tapered caudally, costal and abdominal edges almost parallel, apex wide, rounded, poorly sclerotized; costal margin of valve slightly curved in basal third; transtilla process hook-likely bent, thin, with wide base and tapered apex; juxta large, saddle-lake, with two lateral processes; lateral process of juxta large, elongated, slightly widening caudally, apex rounded; saccus of middle size, semicircle; phallus slightly shorter than valve, of even thickness except for narrowing in basal third; apex of phallus rounded; phallus strongly curved in basal third; vesica aperture in dorsal-apical position, in length about $1 / 4$ of phallus; vesica with thick sickleshaped cornutus; apex of cornutus slightly tapered, cornutus located along phallus axis.

\section{Female}

Unknown.

\section{Remarks}

Paratype the same size as the holotype.

\section{Distribution}

Ethiopia (Debub Omo Zone in the Ethiopian Southern Nations, Nationalities and Peoples' Region (SNNPR).

\section{Flight period}

January.

\section{Discussion}

The genus Afroarabiella Yakovlev, 2008 comprises 11 species. Afroarabiella is one of the Cossidae genera widely spread in Africa (each of them has one representative in Arabia). Ten species of the genus Afroarabiella are found in different parts of Africa (1 species in West Africa, 6 species in East Africa, 2 species in South Africa, 1 species in Sahel) and one (A. tahamae) in South and Central Arabia.

\section{Acknowledgements}

The authors sincerely thank our colleagues - Harald Sulak (Munich) and Manfred Ströhle (Weiden) who collected the new species in Africa. The authors express their thanks to Anna Ustjuzhanina (Tomsk) for the help with the translation of the paper. The English text was corrected by Prof. Boris Kondratieff (Fort Collins). We are indebted to the BMNH Council of Trustees for being so kind and give us permission to publish images of type specimens stored in the Natural History Museum, London.

\section{References}

Lafontaine J.D. 2004. Noctuoidea, Noctuidae (part), Noctuinae (part - Agrotini). In: Hodges R.W. (ed.) The Moths of America North of Mexico, fasc. 27.1. The Wedge Entomological Research Foundation, Washington. 
Mey W. 2015. Revision of the genus Arctiocossus Felder, 1874 and allied genera (Lepidoptera: Cossidae: Cossinae). Annals of the Ditsong National Museum of Natural History 5: 28-55.

Yakovlev R.V. 2008. Afroarabiella gen. nov. - a new genus of Cossidae (Lepidoptera) from the African and Arabian Peninsula. Atalanta 39: 389-395.

Yakovlev R.V. 2014. A new species of Afroarabiella Yakovlev, 2008 (Lepidoptera, Cossidae) from the Republic of South Africa, including a world catalogue of the genus. Zootaxa 3793 (2): 297-300. http:// dx.doi.org/10.11646/zootaxa.3793.2.11

Yakovlev R.V. 2015. Patterns of Geographical Distribution of Carpenter Moths (Lepidoptera: Cossidae) in the Old World. Contemporary Problems of Ecology 8 (1): 36-50. http://dx.doi.org/10.1134/ $\underline{\text { S1995425515010151 }}$

Yakovlev R.V. \& Dubatolov V.V. 2013. Distribution of Carpenter-Moths (Lepidoptera, Cossidae) in the Palaearctic Deserts. Entomological Review 93 (8): 991-1004. http://dx.doi.org/10.1134/ $\underline{\mathrm{S} 0013873813080071}$

Manuscript received: 24 February 2016

Manuscript accepted: 31 May 2016

Published on: 3 November 2016

Topic editor: Gavin Broad

Desk editors: Jeroen Venderickx and Kristiaan Hoedemakers

Printed versions of all papers are also deposited in the libraries of the institutes that are members of the EJT consortium: Muséum national d'Histoire naturelle, Paris, France; Botanic Garden Meise, Belgium; Royal Museum for Central Africa, Tervuren, Belgium; Natural History Museum, London, United Kingdom; Royal Belgian Institute of Natural Sciences, Brussels, Belgium; Natural History Museum of Denmark, Copenhagen, Denmark; Naturalis Biodiversity Center, Leiden, the Netherlands. 